\title{
STRATEGI UNIT PELAKSANA TEKNIS DAERAH (UPTD) DALAM PENGELOLAAN MUSEUM SUBAK DI KABUPATEN TABANAN
}

\author{
Putu Eka Purnamaningsih \\ Program Studi Administrasi Publik \\ Fakultas Ilmu Sosial dan Ilmu Politik, Universitas Udayana \\ Email: eka.ningsih81@gmail.com
}

\begin{abstract}
ABSTRAK
Museum Subak UPTD adalah formedi dengan tujuan melestarikan alat pertanian tradisional yang digunakan oleh organisasi subak kuno. Namun, dalam pengelolaannya masih ada berbagai masalah, yaitu jumlah kunjungan yang rendah dibandingkan dengan TKI lain, kewenangan yang tumpang tindih, dan terbatasnya penggunaan DAK. Dalam menyempurnakan dan / atau membuat strategi, perlu untuk menganalisis strategi menggunakan indikator proses perencanaan strategis menurut John M. Bryson dan juga teknik analisis SWOT menurut Freddy Rangkuti untuk mengidentifikasi peluang, ancaman, kekuatan, dan kelemahan. Jenis penelitian yang digunakan adalah deskriptif kualitatif. Teknik penentuan informan yang digunakan adalah purposive dan snowball. Hasil analisis matriks SWOT menghasilkan delapan strategi alternatif. Strategi keseluruhan yang dijelaskan adalah empat strategi terpilih sebagai skala prioritas untuk Museum UPTD Subak, yaitu memaksimalkan penggunaan teknologi sebagai sarana penyebaran informasi, menumbuhkan semangat bisnis masyarakat untuk menciptakan industri pariwisata di sekitar kawasan Museum Subak, mengembangkan inovasi pemasaran museum untuk menarik pengunjung, mengoptimalkan dukungan dari pemerintah pusat.
\end{abstract}

Kata kunci: Museum UPTD Subak, proses perencanaan strategis, analisis SWOT

\begin{abstract}
UPTD Subak Museum was formed with the aim of preserving traditional farming tools used by ancient subak organizations. However, in its management there are still various problems, namely the low number of visits compared to other DTWs, overlapping authority, and limited use of DAK. In refining and / or making a strategy, it is necessary to analyze the strategy using strategic planning process indicators according to John M. Bryson and also SWOT analysis techniques according to Freddy Rangkuti to identify opportunities, threats, strengths, and weaknesses. The type of research used is descriptive qualitative. The informant determination technique used is purposive and snowball. The results of the SWOT matrix analysis yielded eight alternative strategies. The overall strategies described are four selected strategies as a priority scale for the UPTD Museum Subak, namely maximizing the use of technology as a means of disseminating information, fostering community business spirit to create a tourism industry around the Museum Subak area, developing museum marketing innovations to attract visitors, optimizing support from the central government.
\end{abstract}

Keywords: UPTD Museum Subak, strategic planning process, SWOT analysis 


\section{PENDAHULUAN}

Bali dikenal sebagai pulau yang memiliki eksotisme alam, budaya, serta keramah tamahan masyarakatnya. Subak merupakan salah satu kebudayaan yang dimiliki oleh Pulau Bali. Subak sendiri memiliki pengertian sesuai dengan Peraturan Daerah Provinsi Daerah tingkat I Bali, Nomor 02/PD/DPRD/1972 tentang irigasi (pasal 4 ) menyatakan bahwa "subak adalah masyarakat hukum adat di Bali yang bersifat sosio-agraris-religius, yang secara historis didirikan sejak dahulu kala dan berkembang terus sebagai organisasi penguasa tanah dalam bidang pengaturan air dan lain-lain untuk persawahan dari suatu sumber air di dalam suatu daerah". Petani di Bali membentuk dan mengembangkan organisasi subak. Selain dinilai efektif dalam mengatur air irigasi secara adil dan merata juga mempunyai peran penting lain yaitu pelestarian dan pengembangan seni budaya Bali. Prof. Dr. Ir. Dewa Ngurah Suprapta Guru Besar Fakultas Pertanian Unud mengatakan bahwa Budaya di Pulau Bali ini dikembangkan sebagai wujud nyata ajaran Agama Hindu yang berkaitan dengan bidang pertanian (merdeka.com, 2008).

Kabupaten Tabanan menjadi salah satu kabupaten yang ikut serta dalam mendukung pelestarian subak melalui pembentukan Museum Subak. Selain itu, sebagai daerah yang dikenal memiliki julukan "lumbung padinya Bali", Kabupaten Tabanan membentuk Museum Subak dengan tujuan untuk melestarikan alat-alat pertanian tradisional yang digunakan oleh organisasi subak pada zaman dahulu. Museum Subak berada di bawah tanggung jawab Dinas Kebudayaan Kabupaten Tabanan dan dikelola oleh Unit Pelaksana Teknis Daerah (UPTD) Museum Subak . Hal ini didukung dengan Peraturan Bupati Tabanan Nomor 42 Tahun 2018 tentang Pembentukan, Kedudukan, Susunan Organisasi, Tugas dan Fungsi serta Tata Kerja Unit Pelaksana Teknis Daerah Museum Subak Pada Dinas Kebudayaan Kabupaten Tabanan, dimana pembentkan UPTD ini bertujuan untuk melaksanakan sebagian kegiatan teknis operasional dan atau kegiatan teknis penunjang tertentu perangkat daerah induknya.

Museum Subak selain sebagai tempat untuk mengoleksi dan sarana pembelajaran, juga dikenal sebagai salah satu daerah tujuan wisata (DTW) di Kabupaten Tabanan. Namun, bila dibandingkan daerah tujuan wisata lain di Kabupaten Tabanan jumlah pengunjung ke museum ini tergolong sedikit. Hal ini sesuai dengan data jumlah kunjungan wisatawan di berbagai daerah tujuan wisata Kabupaten Tabanan. 
Tabel 1. Data Kunjungan Wisatawan pada Daerah Tujuan Wisata (DTW) Kabupaten Tabanan 2016 - 2018

\begin{tabular}{|c|l|c|c|c|}
\hline No. & \multicolumn{1}{|c|}{ Nama Obyek } & $\mathbf{2 0 1 6}$ & $\mathbf{2 0 1 7}$ & $\mathbf{2 0 1 8}$ \\
\hline 1 & Ulun Danu Beratan & 707,916 & 947,393 & 967,682 \\
\hline 2 & Bedugul & 37,896 & 18,149 & 0 \\
\hline 3 & Kebun Raya Eka Karya & 570,055 & 468,796 & 616,050 \\
\hline 4 & TPB Margarana & 19,787 & 8,991 & 10,964 \\
\hline 5 & Alas Kedaton & 100,350 & 93,396 & 90,577 \\
\hline 6 & Tanah Lot & $3,524,335$ & $3,497,825$ & $3,335,822$ \\
\hline 7 & Museum Subak & 5,428 & 4,105 & 5,629 \\
\hline 8 & Air Panah Penatahan & 24,045 & 20,356 & 22,580 \\
\hline 9 & Jatiluwih & 213,009 & 250,153 & 277,189 \\
\hline 10 & Taman Kupu-Kupu Lestari & 6,733 & 5,971 & 4,220 \\
\hline 11 & Areal Pura Batukaru & 20,809 & 18,688 & 21,214 \\
\hline \multicolumn{2}{|c|}{ TOTAL } & $5,230,363$ & $5,333,823$ & $5,351,927$ \\
\hline
\end{tabular}

Sumber: Dinas Pariwisata Kabupaten Tabanan, 2019 (diolah)

Berdasarkan tabel data kunjungan wisatawan nusantara dan mancanegara pada daerah tujuan wisata Kabupaten Tabanan periode 2016-2018 khususnya pada Museum Subak sempat mengalami penurunan yaitu pada 2016-2017 sebesar 1.323 wisatawansedangkan pada 2017 sampai 2018 mengalami peningkatan sebanyak 1.524 wisatawan yang berkunjung. Namun, jumlah kunjungan ini masih terbilang sedikit bila dibandingkan dengan DTW Kabupaten Tabanan lainnya.

Selain rendahnya tingkat kunjungan ke Museum Subak ini, ada pula beberapa permasalahan lainnya yaitu terdapat tumpang tindih kewenangan yaitu kawasan Museum Subak dimiliki dan juga dikelola oleh lebih dari satu badan pemerintah sehingga tidak ada kejelasan dalam pengelolaan Museum Subak. Area tanah tempat Museum Subak berdiri merupakan milik Pemerintah Provinsi Bali sedangkan Museum Subak, Kantor Museum Subak, dan rumah adat khas Bali dikelola oleh UPTD Museum Subak bersama dengan Dinas Kebudayaan Kabupaten Tabanan. Di luar dari ketiga bangunan tersebut dikelola oleh Kementrian Pekerja Umum dan Perumahan Rakyat sehingga UPTD Museum Subak maupun Dinas Kebudayaan Kabupaten Tabanan tidak bisa melakukan pembangunan.

Permasalahan lainnya yaitu UPTD Museum Subak mulai 2019 memperoleh Dana Alokasi Khusus (DAK) Non Fisik sehingga pada tahun ini mulai melakukan kegiatan yang melibatkan masyarakat umum di Kabupaten Tabanan. Namun, penggunaan DAK tersebut masih terbatas dikarenakan adanya petunjuk teknik bahwa 
DAK tersebut hanya digunakan untuk kegiatan non fisik sehingga tidak bisa melakukan perbaikan fisik secara besar- besaran di beberapa bangunan padahal banyak bangunan-bangunan di Museum Subak sudah seharusnya diperbaiki seperti rumah bangunan khas Bali yang plafon rumahnya sudah mulai rusak.

Guna mendukung pengelolaan Museum Subak sebagai salah satu museum yang melestarikan subak, dibutuhkan strategi dari Museum Subak selaku pelaku utama dengan pihak pemerintah. Berdasarkan uraian permasalahan di atas, penulis tertarik untuk mengulas lebih jauh strategi UPTD untuk mengelola Museum Subak.

\section{METODE PENELITIAN}

Metode penelitian yang digunakan dalam penelitian ini adalah penelitian kualitatif Singarimbun dan Efendi, 1989:4 menyatakan dimana bahwa penelitian kualitatif merupakan penelitian dengan pendekatan deskriptif, penelitian deskriptif yang dimaksudkan sebagai pengukuran fenomena sosial tertentu yang mampu mengembangkan konsep serta menghimpun fakta tetapi tidak melakukan hipotesis, sebagaimana hasil wawancara akan digunakan serta dijabarkan sehingga menghasilkan analisis deskriptif sebagaimana dalam penelitian kualitatif. Penelitian mengenai Strategi UPTD dalam mengelola Museum Subak di Kabupaten Tabanan menggunakan metode penelitian kualitatif-deskriptif. Informan ditentukan melalui teknik purposive dan snowball. Melalui teknik purposive, menentukan informan sesuai dengan topik penelitian dan yang memahami topik penelitian tersebut. Melalui teknik snowball, penentuan informan secara berantai, teknik penentuan sampel yang mula-mula jumlahnya kecil, kemudian semakin besar.

\section{HASIL DAN PEMBAHASAN}

\section{Proses Perencanaan Strategi}

UPTD Museum Subak dalam menyusun strategi, visi, misi, tujuan serta sasaran ke depannya melalui tahapan perencanaan strategis menurut Bryson (2016) yaitu delapan langkah proses perencanaan strategi. Tahapan ini mencakup analisis lingkungan internal dan eksternal sehingga dapat memberikan gambaran terkait keadaan yang ada di lapangan. Pertama, UPTD Museum Subak telah melakukan indikator pertama yaitu memrakarsai dan menyepakati suatu proses perencanaan strategis dalam wujud penetapan pihak internal dan eksternal (stakehoder) untuk ikut terlibat dalam pengelolaan Museum Subak. Pelaksanaan dalam pengelolaan Museum Subak ini berjalan lancar terbukti dengan adanya pelatihan bahasa inggris untuk meningkatkan kemampuan dari para pegawainya. Pemrakarsa dalam pengelolaan Museum Subak ini yaitu Kepala UPTD Museum Subak. Kedua, UPTD Museum Subak sudah memenuhi indikator kedua yaitu mengidentifikasi mandat organisasi dalam pengelolaan Museum Subak oleh UPTD Museum Subak mendapatkan mandat untuk mengelola Museum Subak melalui Peraturan Bupati Tabanan Nomor 42 Tahun 2018 tentang Pembentukan, Kedudukan, Susunan Organisasi, Tugas dan Fungsi serta 
Tata Kerja Unit Pelaksana Teknis Daerah Museum Subak Pada Dinas Kebudayaan Kabupaten Tabanan dan kewenangan Kepala Dinas Kebudayaan Kabupaten Tabanan melalui Peraturan Bupati No 52 Tahun 2016 Tentang Kedudukan, Susunan Organisasi, Tugas dan Fungsi, serta Tata Kerja Perangkat Daerah Kabupaten Tabanan. Ketiga, UPTD Museum Subak sudah memenuhi indikator ketiga yaitu memperjelas misi dan nilai-nilai organisasi UPTD Museum Subak memiliki visi dan misi sebagai pedoman untuk melestarikan hal-hal tentang subak. Selain itu, UPTD Museum Subak berpatokan pada Renstra (Rencana Strategis) Dinas Kebudayaan Kabupaten Tabanan tahun 2016-2021 yang berpedoman pada visi dan misi daerah dan tertuang dalam RPJMD (Rencana Pembangunan Jangka Menengah Daerah) Kabupaten Tabanan tahun 2016-2021.

Keempat, UPTD Museum Subak sudah memenuhi indikator keempat yaitu menilai lingkungan eksternal: peluang dan ancaman, UPTD Museum Subak telah menilai faktor peluang dan ancaman yang mereka hadapi. Berdasarkan hasil temuan terdapat 4 (empat) faktor peluang dan 2 (dua) faktor ancaman dalam pengelolaan Museum Subak. Kelima, menilai lingkungan internal: kekuatan dan kelemahan , UPTD Museum Subak telah menilai faktor kekuatan dan kelemahan. Terlihat dari hasil temuan yang menjadi penilaian UPTD Museum Subak yaitu telah mencakup sumber daya manusia dan keuangan yang berasal dari APBD Kabupaten Tabanan dan DAK Non Fisik. Namun, sarana dan prasarananya masih luput dari perhatian. Keenam, mengidentifikasi isu strategis yang dihadapi, UPTD Museum Subak berpatokan pada isu strategis yang disusun oleh Dinas Kebudayaan Kabupaten Tabanan yang tercantum dalam Renstra Dinas Kebudayaan Kabupaten Tabanan tahun 2016-2021. Dinas Kebudayaan Kabupaten Tabanan telah melakukan analisis tehadap lingkungan internal dan eksternal untuk mengidentifikasi isu- isu strategis yang dihadapinya kemudian disesuaikan dengan visi, misi, dan tugas dalam urusan kebudayaan.

Ketujuh, merumuskan strategi untuk mengelola isu-isu UPTD Museum Subak menerapkan berbagai strategi untuk mengelola isu-isu tersebut dan diwujudkan dalam bentuk kegiatan-kegiatan. Proses penyusunan strategi ini juga berpedoman dengan Renstra dan aturan-aturan terkait. Terdapat 5 (lima) kegiatan yang dijalankan untuk mengelola Museum Subak. Namun, kegiatan ini masih terdapat kekurangan sehingga nantinya perlu dirumuskan dan disempurnakan kembali agar hasilnya lebih maksimal. Kedelapan, menciptakan visi organisasi yang efektif bagi masa depan UPTD Museum Subak memiliki visi keberhasilan yang berpatokan pada Renstra Dinas Kebudayaan Kabupaten Tabanan tahun 2016-2021. Adapun visi keberhasilannya meliputi tujuan, sasaran, strategi, program dan kegiatan, indikator kinerja kegiatan, dan pendanaan indikatif.

\section{SIMPULAN}

Berdasarkan pembahasan di atas maka dapat disimpulkan UPTD Museum Subak telah menjalankan delapan langkah proses perencanaan strategis menurut 
Bryson (2016). Dalam menjalankannya, dinilai belum optimal seperti ada beberapa poin pada peraturan yang belum dijalankan secara maksimal hingga kurangnya SDM yang mempunyai basic dalam bidang permuseuman. Keseluruhan Strategi SO yang telah dijelaskan, terdapat 4 (empat) strategi yang memiliki potensi untuk mengelola Museum Subak yaitu memaksimalkan pemanfaatan teknologi sebagai sarana penyebarluasan informasi, menumbuhkan jiwa usaha masyarakat untuk membuat industri pariwisata di sekitar area Museum Subak, mengembangkan inovasi pemasaran museum untuk menarik minat pengunjung, dan mengoptimalkan dukungan dari pemerintah pusat.

\section{Referensi}

Anoraga, Pandji. 2009. Manajemen Bisnis. Jakarta: PT. Rineka Cipta

Dinas Kebudayaan Kabupaten Tabanan. 2019. Museum Subak. Tabanan: Dinas Kebudayaan Kabupaten Tabanan

David. Fred. R. 2001. Strategic Management: Concepts \& Cases. New Jersey: Francis Marion University

Issakh, Henki Idris dan Zahrida Wiryawan. 2014. Pengantar Manajemen Edisi 2. Bogor: Penerbit In Media

Naway, Fory A. 2016. Strategi Pengelolaan Pembelajaran. Gorontalo: Ideas Publishing

Pasolong, Harbani. 2014. Teori Administrasi Publik. Bandung.

Satori, D., \& Komariah, A. 2014. Metodologi Penelitian Kualitatif. Bandung. Sinambela,

Thoha, Miftah. 2008. Ilmu Administrasi Publik Kontemporer. Jakarta. Wijaya, Tony. 2011. Manajemen Kualitas Jasa. PT. Indeks, Jakarta Barat

Peraturan Bupati No 52 Tahun 2016 Tentang Kedudukan, Susunan Organisasi, Tugas dan Fungsi, serta Tata Kerja Perangkat Daerah Kabupaten Tabanan

Peraturan Bupati Tabanan Nomor 42 Tahun 2018 tentangPembentukan, Kedudukan, Susunan Organisasi, Tugas dan Fungsi serta Tata Kerja Unit Pelaksana Teknis Daerah Museum Subak Pada Dinas Kebudayaan Kabupaten Tabanan 